\title{
Correction to: Darwin's perception of nature and the question of disenchantment: a semantic analysis across the six editions of $O n$ the Origin of Species
}

\author{
Bárbara Jiménez-Pazos ${ }^{1,2}$ (D)
}

Accepted: 28 June 2021 / Published online: 7 June 2021

(C) The Author(s) 2021

\author{
Correction to: HPLS (2021) 43:57 \\ https://doi.org/10.1007/s40656-021-00373-y
}

Footnotes 24 and 25 in the online version of above mentioned article do not correspond to footnotes 24 and 25 in the downloadable version of the paper (PDF). The correct footnotes 24 and 25 are published in the PDF and read:

${ }^{24} \mathrm{~A}$ more extensive version of this chapter is included in my doctoral thesis (Jiménez Pazos 2016).

${ }^{25}$ Darwin's memories of youth having resulted in a supposed perceptual colour blindness in his old age are included in Journal of Researches: "Among the scenes which are deeply impressed on my mind, none exceed in sublimity the primeval forests undefaced by the hand of man; [...] - no one can stand in these solitudes unmoved, and not feel that there is more in man than the mere breath of his body" (Darwin 1860a, p. 503).

The original article has been corrected.

The original article can be found online at https://doi.org/10.1007/s40656-021-00373-y.

Bárbara Jiménez-Pazos

1 IAS-Research - Centre for Life, Mind and Society, Philosophy Department, University of the Basque Country, San Sebastián, Spain

2 Facultad de Educación, Filosofía Y Antropología, Universidad del País Vasco, Avenida de Tolosa 70, 20018 San Sebastián, Guipúzcoa, Spain 
Open Access This article is licensed under a Creative Commons Attribution 4.0 International License, which permits use, sharing, adaptation, distribution and reproduction in any medium or format, as long as you give appropriate credit to the original author(s) and the source, provide a link to the Creative Commons licence, and indicate if changes were made. The images or other third party material in this article are included in the article's Creative Commons licence, unless indicated otherwise in a credit line to the material. If material is not included in the article's Creative Commons licence and your intended use is not permitted by statutory regulation or exceeds the permitted use, you will need to obtain permission directly from the copyright holder. To view a copy of this licence, visit https://creativecommons.org/licen ses/by/4.0/.

Publisher's Note Springer Nature remains neutral with regard to jurisdictional claims in published maps and institutional affiliations. 